\title{
Uptake of acetylated peptides from the small intestine in sheep and their nutritive value in rats
}

\author{
R. J. Wallace ${ }^{1 *}$, W. K. Min ${ }^{1}$, M. W. Witt ${ }^{1}$, G. Grant ${ }^{1}$, J. C. MacRae ${ }^{1}$, W. J. Maeng ${ }^{2}$, \\ C. J. Newbold ${ }^{1}$ and L. M. Rode ${ }^{3}$ \\ ${ }^{1}$ Rowett Research Institute, Bucksburn, Aberdeen AB21 9SB, UK \\ ${ }^{2}$ Kon-Kuk University, Seoul, South Korea \\ ${ }^{3}$ Agriculture Canada Research Station, Lethbridge, Alberta T1J 4B1, Canada \\ (Received 8 September 1997 - Revised 23 January 1998 - Accepted 13 February 1998)
}

\begin{abstract}
Acetylation is a potential method for protecting dietary peptides from degradation by rumen micro-organisms. As a first step in determining the nutritive value of acetylated peptides, their disappearance in the small intestine of sheep and their ability to support growth in a rat bioassay were measured. ${ }^{15} \mathrm{~N}$-labelled peptides were prepared from lucerne which had been grown with ${ }^{15} \mathrm{~N}$-labelled $\left(\mathrm{NH}_{4}\right)_{2} \mathrm{SO}_{4}$ in the absence of Rhizobium. Peptides were prepared by enzymic hydrolysis of the extracted protein. Two peptide preparations were made using different proteinase mixtures. These mixtures contained peptides with an average molecular weight of 559 and $522 \mathrm{Da}$. They were treated with acetic anhydride, which resulted in 85 and $88 \%$ modification respectively, and their uptake from the small intestine was determined by injecting $1 \mathrm{~g}$ of untreated or acetylated peptides in a Cr-EDTA solution into the jejunum of two sheep fitted with jejunal catheters and ileal cannulas. Ileal digesta were collected and analysed for $\mathrm{Cr}$ and ${ }^{15} \mathrm{~N}$. The uptake of dialanine $\left(\mathrm{Ala}_{2}\right)$ and $\mathrm{N}$-acetyl-Ala ${ }_{2}$ were compared in a similar way. The disappearance of ${ }^{15} \mathrm{~N}$ from lucerne peptides was high ( 88 and $93 \%$ respectively) and this was not affected significantly by acetylation ( 86 and $87 \%$ ). Corresponding values for $\mathrm{Ala}_{2}$ and $\mathrm{N}$-acetyl$\mathrm{Ala}_{2}$ were both $96 \%$, as measured by HPLC. It was therefore concluded that acetylation did not affect the uptake of peptides from the small intestine in sheep. Two feeding trials were carried out with rats. The first trial was carried out with a protein-free diet to which was added $10 \%$ lactalbumin or $5 \%$ lactalbumin and then a mixture of methionine-free amino acids, either alone or supplemented with Met, Gly-Met or acetylated Gly-Met. The rats grew equally well on all sources of Met, but failed to grow significantly on the mixture of Met-free amino acids. In the second trial the diet contained casein as $5.9 \%$ of the basal diet. Additional casein, pancreatic casein hydrolysate (peptides) and acetylated pancreatic casein hydrolysate (acetylated peptides) were compared as sources of amino acids, at inclusion rates of $100 \mathrm{~g} / \mathrm{kg}$ final diet. Feed intake was similar with casein and peptides treatments, but was depressed by $23 \%$ with acetylated peptides. Live weight gain was 15 and $75 \%$ lower with the peptides and acetylated peptides diets respectively. Addition of lysine, arginine or histidine did not restore feed intake or weight gain of rats receiving acetylated peptides, but feed intake was restored immediately when peptides replaced acetylated peptides. When intake was restricted to $9 \mathrm{~g} / \mathrm{d}$ and acetylated casein hydrolysate replaced half of the protein in the diet, rats gained weight less rapidly $(1.44 v$. $1.09 \mathrm{~g} / \mathrm{d}$ ) and retained less $\mathrm{N}$, such that only 0.36 of the acetylated peptide- $\mathrm{N}$ was calculated to remain available to the animal. This $\mathrm{N}$ retention compared with 0.70 for unmodified casein. Thus, the rat bioassay indicated that certain specific peptides may well be of high nutritive value following acetylation, but that there may be problems of inappetance and inefficient utilization with acetylated peptide mixtures.
\end{abstract}

Acetylated peptides: Small intestine: Nutritive value: Sheep: Rat 
Protected protein and amino acids are potentially important sources of amino acids for protein synthesis in ruminants, as they avoid the wasteful metabolism of these nutrients by rumen micro-organisms and they can correct imbalances in the composition of amino acids reaching the small intestine (Leng \& Nolan, 1984). Various physical or chemical methods are available for their protection (Kaufmann \& Lupping, 1982; Broderick et al. 1991; Schwab, 1995). The observation that microbial peptidase activity in the mixed rumen microbial population acts almost exclusively from the N-terminus of small peptides (Wallace \& McKain, 1989; Wallace et al. 1990) led to the suggestion that peptides might be protected by chemical modification of N-terminal amino groups (Wallace, 1992a; Wallace et al. 1993). Small peptides are protected very effectively from degradation in rumen fluid in vitro by this method (Wallace, 1992a; Wallace et al. 1993), and the rumen microbial population did not adapt to break down acetylated peptides after 4 weeks of dietary supplementation (Witt et al. 1998).

If chemically modified peptides are to be of nutritional value to ruminants, their constituent amino acids must be absorbed from the small intestine and be made available for protein synthesis. This study was undertaken to determine the intestinal uptake of acetylated peptides and their nutritive value in a rat bioassay.

\section{Materials and methods}

\section{Preparation of ${ }^{15} \mathrm{~N}$-labelled peptides from lucerne}

Lucerne seeds were grown in an artificial soil mixture, from which N-fixing Rhizobium spp. were excluded. After approximately 4 weeks the seedlings were replanted in $200 \mathrm{~mm}$ pots with a sterile, N-free artificial soil mixture. Plants were then fertilized with a complete mineral fertilizer mixture minus $\mathrm{N}$ plus $8 \mathrm{ml}$ per pot of an $\left(\mathrm{NH}_{4}\right)_{2} \mathrm{SO}_{4}$ solution $\left(58.96 \mathrm{~g}\left(\mathrm{NH}_{4}\right)_{2} \mathrm{SO}_{4} / 1 ; 10 \%{ }^{15} \mathrm{~N}\right.$-enrichment). Plants were kept in a greenhouse and every $21 \mathrm{~d}$, growth was clipped to within $20 \mathrm{~mm}$ of the soil surface and the pot was refertilized with the ${ }^{15} \mathrm{~N}$-solution $(8 \mathrm{ml})$. The harvested forage was air-dried then ground through a Wiley mill (10 $\mathrm{mm}$ screen). Protein was extracted in an SDS-buffer solution containing $30 \mathrm{~g} \mathrm{SDS}, 40 \cdot 87 \mathrm{~g}$ sodium borate decahydrate and $4.56 \mathrm{~g}$ sodium phosphate, dibasic (anhydrous)/1 of solution, $20 \mathrm{ml}$ of this solution being used/g of forage. The final $\mathrm{pH}$ of the solution was adjusted to $7 \cdot 0$, then the ground forage mixture was boiled for $2 \mathrm{~h}$ under reflux then filtered through Whatman No. 4 filter paper. The residue was washed with hot SDS-buffer and the filtrate was cooled overnight at $5^{\circ}$. Cold $\mathrm{HClO}_{4}$ was added (0.5\% final concentration) and the protein extract was centrifuged at $20000 \mathrm{~g}$ for $15 \mathrm{~min}$. The precipitate was then freeze-dried.

\section{Acetylation of peptides}

Two peptide mixtures were prepared by methods based on those described by Chataud et al. (1987). For both preparations, $15 \mathrm{~g}^{15} \mathrm{~N}$-lucerne protein were suspended in $100 \mathrm{ml}$ $\mathrm{H}_{2} \mathrm{O}$ and incubated at $45^{\circ}$. The $\mathrm{pH}$ was adjusted to 9.0 by addition of $5 \mathrm{M}-\mathrm{NaOH}$, then $1.5 \mathrm{ml}$ of Alcalase (from Bacillus licheniformis; Novo Nordisk Industries UK,
Farnham, Surrey, UK) was added. For the first preparation (A) the mixture was incubated for $4.5 \mathrm{~h}$, maintaining the $\mathrm{pH}$ at $9 \cdot 0$, then boiled for $2 \mathrm{~min}$ to inactivate enzymes, centrifuged at $5000 \mathrm{~g}$ to remove particles and dried by rotary evaporation. For the second preparation (ANP), 5 min after the addition of Alcalase the $\mathrm{pH}$ was adjusted to 8.0 and $1.5 \mathrm{ml}$ of Neutrase (from Bacillus subtilis; Novo Nordisk Industries UK) was added. After another 5 min the $\mathrm{pH}$ was adjusted to 8.0 and $0 \cdot 15 \mathrm{~g}$ pancreatic enzyme mixture (PEM 2500, Novo Nordisk Industries UK) was added. The mixture was incubated for $4.5 \mathrm{~h}$ at $45^{\circ}$, maintaining the $\mathrm{pH}$ at 8.0 for the first hour by adding $\mathrm{NaOH}$, then was boiled, centrifuged and freeze-dried as for preparation A. The efficiency of the reaction was checked using ninhydrin (Moore \& Stein, 1954), and the molecular weight distribution and average molecular weight of the peptides generated were determined by gel filtration as described previously (Wallace, 1992b). Dialanine $\left(\mathrm{Ala}_{2}\right.$; Sigma) and both peptides preparations were treated with acetic anhydride as described previously (Witt et al. 1998). The efficiency of the reaction was checked once again with ninhydrin.

\section{Measurements of peptide survival in the small intestine of sheep}

Availability of acetylated peptides to the host animal will be dependent on their absorption from the small intestine. This was assessed in sheep using a variation of the procedure originally used by Poppi et al. (1986) to assess the intestinal disappearance of ${ }^{35} \mathrm{~S}$-labelled microbial protein. In the present study, two adult sheep (live weight approximately $40 \mathrm{~kg}$ ) were prepared with T-shaped cannulas in the jejunum, about $2 \mathrm{~m}$ from the start of the small intestine, and ileum (Hecker, 1974). They were housed in metabolism cages and given a ration comprising a grass and hay mix, barley, molasses, fishmeal and a vitamin-mineral supplement $(500,300,100,91,9 \mathrm{~g} / \mathrm{kg}$ DM respectively) at $800 \mathrm{~g} / \mathrm{d}$ by frequent (hourly) feeds. On the day of the experiment, $1 \mathrm{~g}$ of the peptides or acetylated peptides mixtures or $0.1 \mathrm{~g}$ of $\mathrm{Ala}_{2}$ or $\mathrm{N}$-acetyl-Ala $\mathrm{A}_{2}$ were introduced into the jejunum in $50 \mathrm{ml} \mathrm{Cr}$-EDTA solution, containing $2.77 \mathrm{~g} \mathrm{Cr} / 1$ prepared as described by Binnerts et al. (1968). Samples of ileal digesta were collected for hourly periods over the next $5 \mathrm{~h}$. The samples were weighed, then an equal weight of TCA $(100 \mathrm{~g} / \mathrm{l})$ was added and the samples were stored at $4^{\circ}$. Analyses were done on supernatant fractions after centrifugation at $26000 \mathrm{~g}$ for $15 \mathrm{~min}$. Cr was determined by diluting the samples 1000-fold and analysing by atomic absorption spectrometry. $\mathrm{Ala}_{2}$ and $\mathrm{N}$-acetyl-Ala $\mathrm{A}_{2}$ were detected using reverse-phase ion-pairing HPLC (Wallace \& McKain, 1989). ${ }^{15} \mathrm{~N}$ was determined by isotope ratiomass spectrometry as described by Barrie \& Workman (1984) and $\mathrm{N}$ was measured by a micro-Kjeldahl procedure (Davidson et al. 1970).

Each peptide preparation in acetylated and unprotected form was introduced into each sheep on two separate occasions. The results were calculated using values from the two samples on each occasion which had the highest concentrations of $\mathrm{Cr}$; these were always sequential samples, but the first such sample was sometimes in the $1-2 \mathrm{~h}$ collection, although more often in the $2-3 \mathrm{~h}$ sample. The 
results are therefore the means of eight values: two samples from each of two days, using two sheep. Disappearance of acetylated peptide was assessed as:

$\frac{{ }^{15} \mathrm{~N}: \mathrm{Cr}-\text { EDTA in infusate }-{ }^{15} \mathrm{~N}: \mathrm{Cr} \text {-EDTA in ileal digesta }}{{ }^{15} \mathrm{~N}: \mathrm{Cr} \text {-EDTA in infusate }}$.

\section{Nutritive value of acetylated peptides for rats}

Trial 1. Twenty Lister Hooded rats ( $40 \mathrm{~d}$ old) were given diets containing lactalbumin as sole protein source or similar diets where half the lactalbumin was replaced with amino acids or peptides. The control semi-synthetic diet contained $100 \mathrm{~g}$ lactalbumin protein/kg diet (Table 1). Test diets contained $50 \mathrm{~g}$ of lactalbumin $/ \mathrm{kg}$ plus an amino acid mixture in sufficient quantity to give the equivalent of $100 \mathrm{~g}$ of total protein $/ \mathrm{kg}$ diet. Test diet A contained $50 \mathrm{~g} / \mathrm{kg}$ of a free amino acids mixture equivalent to casein but lacking methionine, and diet $\mathrm{B}$ contained the same amount of free amino acids mixture plus $1.25 \mathrm{~g}$ L-methionine $/ \mathrm{kg}$. In diet $\mathrm{C}$ the methionine was replaced by $1.72 \mathrm{~g}$ Gly-Met and in diet $\mathrm{D}$ with acetylated Gly-Met. The rats received $8 \mathrm{~g}$ diet daily, in two equal meals, for $10 \mathrm{~d}$. The intake was equivalent to that which rats given diet A would eat each day if fed ad libitum and was well above that required $(6 \cdot 0 \mathrm{~g} / \mathrm{rat}$ per $\mathrm{d})$ to supply minimum requirements for energy, vitamins and minerals.

Trial 2. Eighteen male Lister Hooded rats, $27 \mathrm{~d}$ old and weighing $78-82 \mathrm{~g}$, were allocated to one of six blocks according to their live weight and then one rat from each block was allocated randomly to one of three diets. The control diet contained $100 \mathrm{~g}$ casein protein $/ \mathrm{kg}$ (Table 1 ). The test diets contained $50 \mathrm{~g}$ casein protein $/ \mathrm{kg}$ plus $50 \mathrm{~g}$ pancreatic casein hydrolysate ('peptides'; Peptone 140, Gibco BRL, Life Technologies, Paisley, Scotland, UK), or peptides treated with acetic anhydride to provide $71.5 \%$ modification of free amino groups (Witt et al. 1998). Rats were housed individually and fed on the casein-supplemented diet ad libitum for $5 \mathrm{~d}$ before the start of the experiment. Thereafter, rats were offered the experimental diets and water ad libitum. They were weighed daily and their feed consumption was recorded. Lysine $(3 \cdot 1 \mathrm{~g} / \mathrm{kg}$ diet $)$ was added from days $7-14$, and histidine and arginine (1.3 and $2.5 \mathrm{~g} / \mathrm{kg}$ ) were added from days $10-14$. The rats receiving

Table 1. Composition of the control ( $100 \mathrm{~g}$ protein $/ \mathrm{kg}$ ) diets fed to rats. Test diets were formulated by substitution of half of the protein of the diets with amino acid or peptide mixtures

\begin{tabular}{lcc}
\hline & \multicolumn{2}{c}{ Inclusion rate $(\mathrm{g} / \mathrm{kg})$} \\
\cline { 2 - 3 } Constituent & Trial 1 & Trials 2 and 3 \\
\hline Lactalbumin & 120 & 0 \\
Casein & 0 & 118 \\
Maize starch & 380 & 382 \\
Potato starch & 100 & 100 \\
Glucose & 150 & 150 \\
Maize oil & 150 & 150 \\
Vitamins & 50 & 50 \\
Minerals & 50 & 50 \\
Silicic acid & 0.8 & 0.8 \\
\hline
\end{tabular}

acetylated peptides were switched to the peptide diet from days 14-17. Faeces were collected on days 7 and 9 and analysed for $\mathrm{N}$ content by a micro-Kjeldahl method (Davidson et al. 1970).

Trial 3. A third feeding trial was undertaken with rats to investigate the effects of feeding either acetylated peptides or casein when fed on an equal intake basis. All rats consumed $9 \mathrm{~g}$ ration/d, six receiving the caseincontaining diet and six receiving a ration where half the casein was replaced by acetylated casein hydrolysate. Measurements of live-weight gain and $\mathrm{N}$ balance were made over a $10 \mathrm{~d}$ period.

\section{Results}

Efficiency of acetylation procedure in protecting peptides from microbial degradation

The average molecular weight of peptides in the mixtures was calculated from the number of free $\mathrm{NH}_{2}$ groups as determined using ninhydrin, and compared with Trypticase, which was characterized in a previous study (Wallace, $1992 b)$. The use of Alcalase alone resulted in an average molecular weight of $559 \mathrm{Da}$, and the proteinase mixture containing both bacterial and pancreatic proteinases gave an average molecular weight of $522 \mathrm{Da}$, almost exactly the same as Trypticase. The molecular weight distribution of the unmodified mixtures was assessed by Sephadex G-25 chromatography. The distribution of molecular weights was similar in both preparations, and both had a narrower range of molecular weight than Trypticase; in particular, free amino acids were much lower (results not shown).

The acetylation procedure resulted in fairly effective protection of all peptides. More than $89 \%$ of the free amino group content of $\mathrm{Ala}_{2}$ was blocked, and values of 85 and $88 \%$ were obtained for preparations A and ANP respectively.

\section{Availability of acetylated peptides for host animal metabolism}

Data on the proportional disappearance of the acetylated and unprotected peptides between the jejunum and ileum of two sheep are given in Table 2. Acetylation appeared to have little effect on the availability of the different peptide preparations for host animal metabolism. There was, however, a tendency for the availability of the dipeptide $\mathrm{Ala}_{2}$ to be higher than for the higher molecular weight mixed peptide preparations.

\section{Nutritive value of acetylated peptides for rats}

Trial 1. Acetylation of Gly-Met. Substitution of the amino acid mixture minus methionine (diet A) for the lactalbumin had a severe $(P<0.05)$ effect on live-weight gain and food conversion efficiency of the rat (Table 3 ). However, supplementation of this diet with either methionine (diet B), unprotected Gly-Met (diet C), or acetylated Gly-Met (diet D) were all equally effective in reinstating the growth rate and feed conversion efficiency to levels which were not significantly different from those achieved with the control 
Table 2. Influence of acetylation on absorption of ${ }^{15} \mathrm{~N}$-labelled peptides and $\mathrm{Ala}_{2}$ from the small intestine of sheep

(Mean values and standard deviations of two injections carried out on two sheep on each of two days)

\begin{tabular}{lcclll}
\hline & \multicolumn{3}{c}{ Absorption from the small intestine (\%) } \\
\cline { 2 - 3 } \cline { 5 - 6 } \cline { 5 - 6 } Peptide & \multicolumn{2}{c}{ Unmodified } & & \multicolumn{2}{c}{ Acetylated } \\
\cline { 2 - 3 } \cline { 5 - 6 } & Mean & SD & & Mean & SD \\
\hline Peptides A & 87.7 & 1.7 & & 86.1 & 4.2 \\
Peptides ANP & 92.7 & 3.4 & & 87.5 & 5.5 \\
Ala $_{2}$ & 95.7 & 4.7 & & 96.1 & 3.0 \\
\hline
\end{tabular}

diet. Thus, the rats appeared to be able to utilize acetylated Gly-Met as a source of methionine for their protein metabolism requirements.

Trial 2. Ad libitum feeding. Mean live-weight gains of rats given the casein and the peptides-supplemented diets $(5.4$ and $4.6 \mathrm{~g} / \mathrm{d}$; see Fig. 1$)$ were higher $(P<0.05)$ than those given the acetylated peptides-supplemented diet $(1.4 \mathrm{~g} / \mathrm{d})$. Feed intake was not significantly different with the casein and peptides diets, but was decreased by $23 \%$ $(P<0.05)$ with the acetylated peptides (Fig. 2). Lysine, which was added to the acetylated peptides diet from day 7 onwards, and histidine and arginine added from day 10 onwards, had little effect on either weight gain (Fig. 1) or intake (Fig. 2). When the rats receiving acetylated peptides were switched to the diet containing untreated peptides on days $14-17$, feed intake rose rapidly to the same as the other groups, and live-weight gain also increased. Faecal $\mathrm{N}$ excretion was not significantly different between treatments $(10.22,9.06$ and $9.43 \mathrm{mg} / \mathrm{d}$ for casein, peptides and acetylated peptides treatments respectively; df 10, SED $0.581)$

Trial 3. Restricted feeding. In order to eliminate the difficulties of interpretation introduced by the decreased food intake with acetylated peptides in Trial 2, a further experiment was conducted with two groups of rats, one fed on a ration in which $50 \%$ of the casein was replaced with acetylated casein hydrolysate and the other group, which acted as a pair-fed control (on an intake basis), where the ration contain untreated casein. The pair-fed group grew more quickly and retained more $\mathrm{N}$ than the group given the acetylated peptides (Table 4). However, $\mathrm{N}$ retention fell by only $21 \%$ with the acetylated peptides.

\section{Discussion}

The methods used here to prepare peptides from ${ }^{15} \mathrm{~N}$-labelled lucerne protein were developed to provide mixtures rich in di- and tripeptides (Chataud et al. 1987). The average molecular weights indicated a mean chain length of about five amino acids; however, the distribution of molecular weights indicated few free amino acids. Thus most of the peptides in the mixtures would be expected to be of a molecular weight similar to pancreatic casein hydrolysate, where acetylation provides effective protection from ruminal degradation (Wallace, 1992a). Furthermore, both the casein hydrolysate and the ANP lucerne

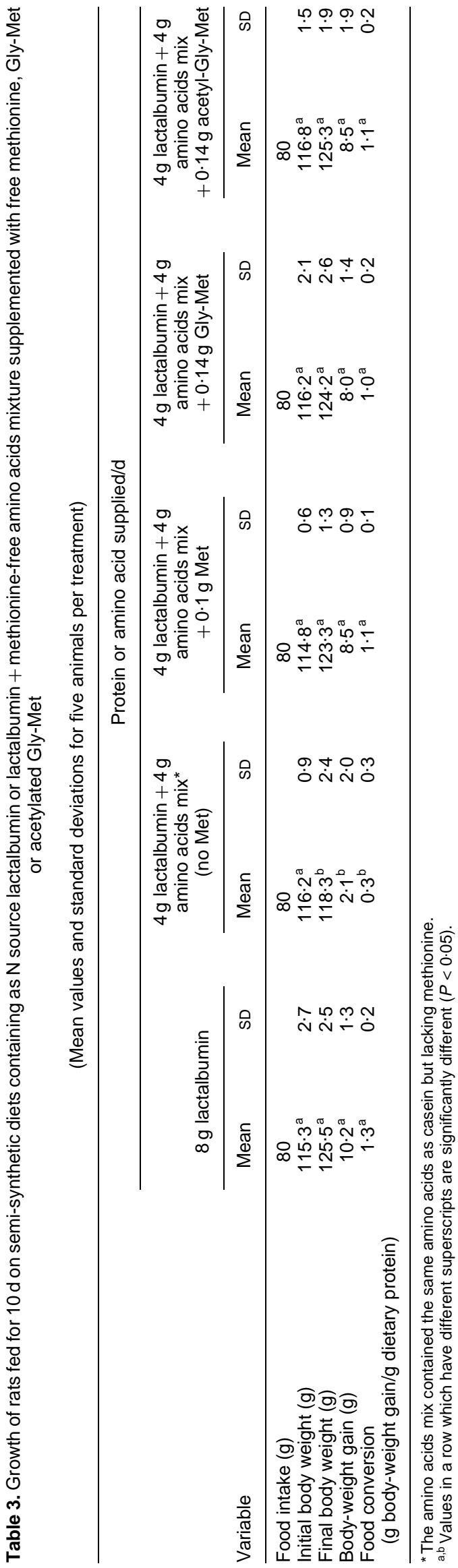




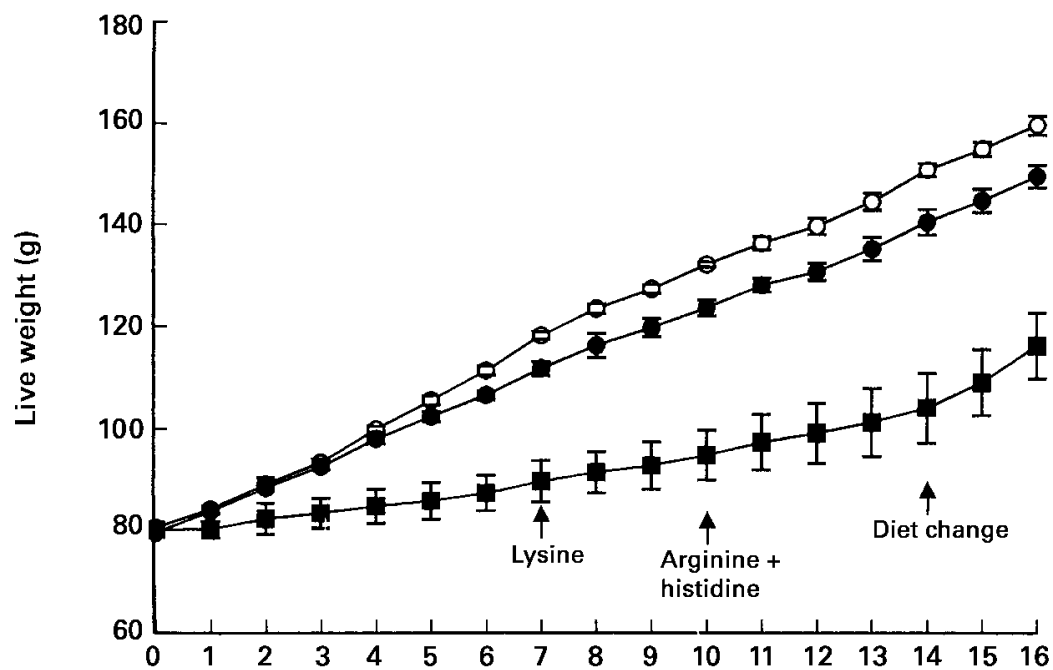

Period on diet (d)

Fig. 1. Live-weight gain of rats receiving ad libitum basal semi-synthetic diet plus casein $(100 \mathrm{~g}$ protein $/ \mathrm{kg}$ diet) $(0)$, casein $(50 \mathrm{~g}$ protein $/ \mathrm{kg})+$ enzymic casein hydrolysate $(50 \mathrm{~g} / \mathrm{kg})(\bullet)$, or casein $(50 \mathrm{~g}$ protein $/ \mathrm{kg})+$ acetylated enzymic casein hydrolysate $(50 \mathrm{~g} / \mathrm{kg})(\mathbf{\square})$, (Trial 2). Lysine $(3.1 \mathrm{~g} / \mathrm{kg})$ was added to the diet from day 7 onwards, arginine $(1.3 \mathrm{~g} / \mathrm{kg})$ and histidine $(2.5 \mathrm{~g} / \mathrm{kg})$ from day 10 onwards, and acetylated casein hydrolysate was replaced by untreated casein hydrolysate on day 14. Mean values for six animals per treatment, with standard deviations represented by vertical bars.

hydrolysate were the result of digestion by pancreatic enzymes, and although there would be many hundreds of peptides of different sequence and composition in the lucerne hydrolysate while perhaps only as few as one hundred in the casein hydrolysate, there is no reason to suppose that the smaller number of peptides present in the casein hydrolysate would behave differently in their absorption or nutritional properties.

The acetylation procedure adopted was different from that used previously (Wallace, 1992a), in that the solution

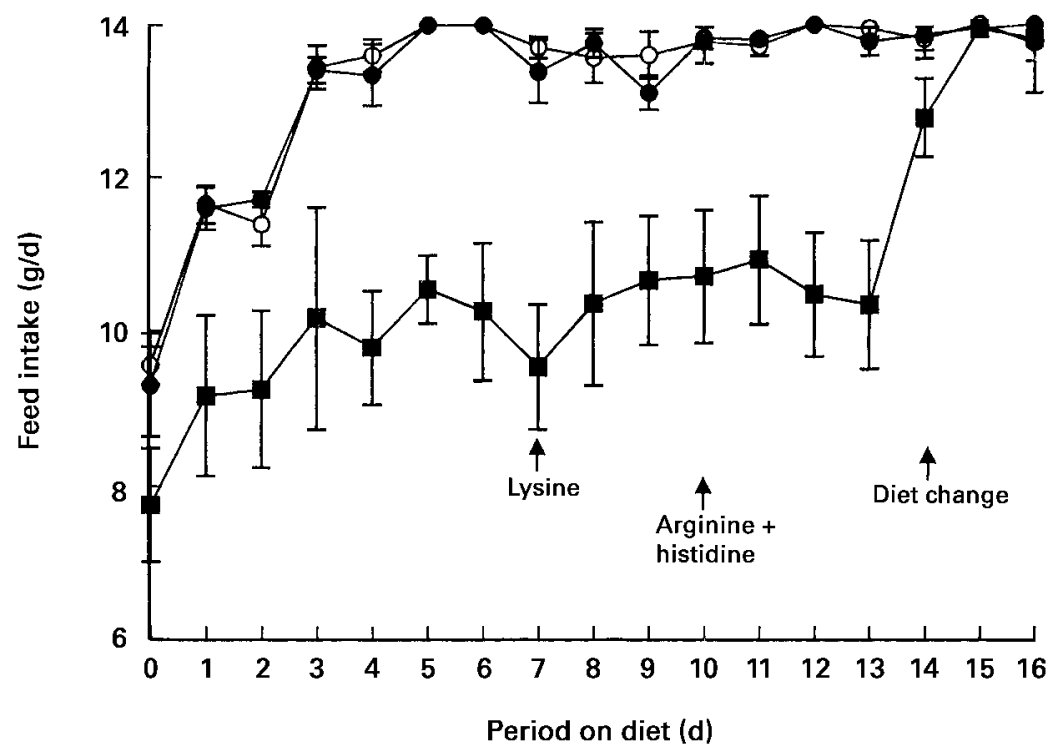

Fig. 2. Feed intake of rats receiving ad libitum basal semi-synthetic diet plus casein $(100 \mathrm{~g}$ protein $/ \mathrm{kg}$ diet $)(O)$, casein $(50 \mathrm{~g}$ protein $/ \mathrm{kg})+$ enzymic casein hydrolysate $(50 \mathrm{~g} /$ $\mathrm{kg})(\bullet)$, or casein $(50 \mathrm{~g}$ protein $/ \mathrm{kg})+$ acetylated enzymic casein hydrolysate $(50 \mathrm{~g} / \mathrm{kg})$

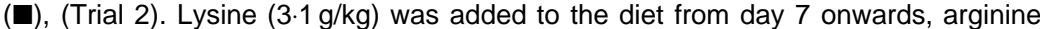
$(1.3 \mathrm{~g} / \mathrm{kg})$ and histidine $(2.5 \mathrm{~g} / \mathrm{kg})$ from day 10 onwards, and acetylated casein hydrolysate was replaced by untreated casein hydrolysate on day 14 . Mean values for six animals per treatment, with standard deviations represented by vertical bars. 
Table 4. Nutritional performance of rats fed for $10 \mathrm{~d}$ on a restricted intake $(9 \mathrm{~g} / \mathrm{d})$ of a semi-synthetic diet containing casein or casein + acetylated pancreatic casein hydrolysate as $\mathrm{N}$ source (Trial 3 )

(Mean values and standard deviations for six rats per treatment)

\begin{tabular}{|c|c|c|c|c|}
\hline \multirow[b]{3}{*}{ Variable } & \multicolumn{4}{|c|}{ Protein provided/d } \\
\hline & \multicolumn{2}{|c|}{$9 \mathrm{~g}$ casein } & \multicolumn{2}{|c|}{$\begin{array}{c}4.5 \mathrm{~g} \text { casein } \\
+4.5 \mathrm{~g} \text { acetylated } \\
\text { casein hydrolysate }\end{array}$} \\
\hline & Mean & SD & Mean & SD \\
\hline Food intake (g) & 90 & & 90 & \\
\hline $\mathrm{N}$ intake $(\mathrm{mg})$ & 1460 & & 1390 & \\
\hline Body-weight gain (g) & $14 \cdot 4^{\mathrm{a}}$ & $1 \cdot 2$ & $10 \cdot 9^{b}$ & 1.5 \\
\hline $\begin{array}{l}\text { Food conversion } \\
\text { (g body-weight gain/g dietary protein) }\end{array}$ & $1 \cdot 6^{a}$ & $0 \cdot 1$ & $1 \cdot 2^{b}$ & $0 \cdot 1$ \\
\hline Faecal N (mg) & 185 & 35 & 190 & 22 \\
\hline Urinary N (mg) & $252^{\mathrm{a}}$ & 33 & $389^{b}$ & 50 \\
\hline $\mathrm{N}$ retained $(\mathrm{mg})$ & $1023^{a}$ & 55 & $812^{b}$ & 49 \\
\hline
\end{tabular}

${ }^{a, b}$ Values in a row which have different superscripts are significantly different $(P<0.05)$.

of acetic anhydride did not contain sodium acetate and acetylation was carried out for $1 \mathrm{~h}$ compared with $24 \mathrm{~h}$, both of which measures were adopted in order to make the process simpler. The efficiency of protection of $\mathrm{Ala}_{2}$, GlyMet and peptides prepared from lucerne remained around $90 \%$, similar to that found with the previous procedure (Wallace, 1992a), but the efficiency of protection decreased to $72 \%$ with the casein hydrolysate. Clearly it would be possible to improve the efficiency of chemical modification; however, inefficient protection need not be an undesirable feature of peptide protection, as the unmodified peptides might benefit microbial growth in the rumen (Argyle \& Baldwin, 1979).

Previous studies have shown that acetylation inhibits the breakdown of small peptides by rumen micro-organisms (Wallace, 1992a; Wallace et al. 1993) and that rumen micro-organisms do not adapt to utilize acetylated peptides for a period of up to 4 weeks (Witt et al. 1998). If acetylated peptides are to be useful nutritionally for ruminants, the subsequent absorption and metabolic availability of their constituent amino acids must not be compromised. Two groups of experiments were therefore undertaken. In the first, the uptake of acetylated peptides from the small intestine was investigated in sheep cannulated in the jejunum and ileum. The nutritive value of the constituent amino acids was assessed by a standard protein bioassay, namely the growing rat. Both groups of experiments were considered important preliminaries before full nutritional trials in sheep and cattle.

The absorption of peptides was determined by their disappearance during passage through the small intestine of sheep. Cr-EDTA was injected in the same solution as the peptides as a marker of liquid flow. Cr concentrations in subsequent ileal samples were highly variable, indicating poor mixing within the digesta, but were highest $1-3 \mathrm{~h}$ after feeding. Some peptide or peptide- ${ }^{15} \mathrm{~N}$ remained in ileal samples, and the extent of disappearance was calculated by comparison with the $\mathrm{Cr}$ concentration. It was assumed for these calculations that both $\mathrm{Cr}$ and peptides remained entirely associated with the liquid phase of the digesta. Although this was not checked, neither peptides nor
Cr-EDTA would be expected to become associated with solids. These calculations indicated that the amounts of peptides remaining in ileal digesta were low, that there was no significant difference between different peptides in their absorption, and that acetylation had no significant influence on absorption. The distribution of $\mathrm{N}$ between faeces and urine in rat trials was also consistent with unimpaired uptake of acetylated peptides from the small intestine. However, neither experiment distinguishes whether hydrolysis preceded absorption or the acetylated peptides were absorbed intact.

The rats used as a bioassay of the nutritive value of acetylated peptides were given, in separate experiments, the pure dipeptide Gly-Met and pancreatic casein hydrolysate, both in unmodified and acetylated form. Gly-Met was supplied to a methionine-deficient diet, and the results indicated that acetylation of the dipeptide had no influence on the subsequent uptake and metabolism of the constituent methionine. The peptide mixture replaced part of the protein of the diet. The unmodified mixture was used efficiently, but acetylation caused problems with the ad libitum food intake of the rats and on the biological value of the absorbed protein. The lower food intake could have been caused by one or more of the following factors: poor palatability (peptides are often bitter to taste); damage to amino acid residues by acetylation; incomplete deacetylation in the absorbed peptides; or a metabolic disturbance caused by the acetyl groups released. The present experiments do not resolve what the problem is, but some useful pointers can be made.

Acetic anhydride reacts with both N-terminal amino groups and some amino acid side-chains. The Gly-Met experiment showed that Met is not damaged, so if damage to amino acid residues is responsible for the lower nutritive value of the acetylated mixture, other residues must be affected. Studies with N-acetyl-tyrosine suggest that its nutritive value depends on tissue acetylase activities (Neuhäuser et al. 1985; Van Goudoever et al. 1994). $\mathrm{N}$-Acetyl-tyrosine has a low bioavailability in the piglet (Wykes et al. 1994). In the present experiments, only the minority of amino acids in a peptide mixture will be affected 
by $\alpha$-amino-acetylation however. Side-chain modifications were thought likely to be a greater problem. Among the side-chains most likely to be affected by acetic anhydride is lysine (Means \& Feeney, 1971). Acetylation of the $\varepsilon$-amino group of lysine decreases its availability by $50 \%$ (Neuberger \& Sanger 1943; Carpenter \& Booth, 1973); however, the addition of lysine to the acetylated peptidescontaining diet did not restore its nutritive value. Other side-chain reactions with amino-groups would be expected to occur, but with the exception of histidine, these would be expected to occur only with non-essential amino acids (Means \& Feeney, 1971). Adding back the essential amino acids most likely to be modified by acetylation failed to restore intake, so damage to an individual amino acid seems unlikely to be the cause of the problem. In comparison, replacement of acetylated casein hydrolysate by untreated casein hydrolysate restored feed intake and weight gain within $2 \mathrm{~d}$.

A further rat feeding trial was carried out with restricted feeding in order to eliminate the intake effect. The pair-fed group grew more quickly and retained more $\mathrm{N}$ than the group given the acetylated peptides. The value of acetylated peptides was therefore less than the untreated casein. Faecal $\mathrm{N}$ was unchanged, consistent with the earlier conclusion that acetylated peptides were taken up from the gut. The actual extent of utilization can be estimated from the values given in Table 4. The diet of the treatment group contained equal parts of casein and acetylated casein hydrolysate, which was $72 \%$ acetylated. The casein-N supplied in the treatment diet was therefore $0.5 \times 1460=730 \mathrm{mg}$, so the acetylated casein hydrolysate provided $1390-730=660 \mathrm{mg} \mathrm{N}$, of which $(1.00-0.72) \times 660=185 \mathrm{mg}$ was present in the form of unmodified casein hydrolysate. The combined, non-acetylated portion of the treatment diet therefore contained $730+185=915 \mathrm{mg} \mathrm{N}$. If it is assumed that the same proportion of this $\mathrm{N}$ was retained as it was from casein in the control diet, $915 \times 1023 / 1460=641 \mathrm{mg}$ of the $\mathrm{N}$ retained from the treatment diet must have been derived from non-acetylated protein and peptides. By difference, the $\mathrm{N}$ retained from acetylated peptides was therefore $812-641=171 \mathrm{mg} \mathrm{N}$. Thus the retention of $\mathrm{N}$ in acetylated peptides was $171 /(0 \cdot 72 \times 660)=0 \cdot 36$. This compared with $\mathrm{N}$ retention from casein of $1023 / 1460=0 \cdot 70$. Thus, under the circumstances of feeding used in Trial 3, the acetylated extract retained about half of the nutritive value of unmodified casein.

\section{Implications}

Acetylation of peptides has been proved to be effective in protecting peptides from degradation by rumen microorganisms. If dietary acetylated peptides are to be useful nutritionally, the acetylated peptides flowing from the rumen must be absorbed and their constituent amino acids utilized efficiently. The present experiments demonstrate that acetylated peptides are absorbed from the small intestine of sheep to a similar extent to unmodified peptides. The rat bioassays indicate that there may be problems in their subsequent utilization however. Some individual peptides, such as Gly-Met, may not be affected, and conceivably the acetylation of Gly-Met, for example, could form the basis of a new method to deliver protected methionine to the abomasum. Many more experiments with different peptides and amino acids would be necessary to determine the applicability of such a method. But, for reasons which are not clear, the availability of $\mathrm{N}$ in acetylated mixed peptides was limited to about half that of casein; furthermore, there were problems with inappetance when acetylated peptides made up a substantial proportion of the rat diet. Similar metabolic problems might well occur in ruminants. Thus, the acetylation of peptide mixtures will not be a useful means of providing rumen-protected amino acid mixtures until the biochemical basis of these problems is resolved.

\section{Acknowledgement}

The authors thank Les Bruce for expert advice in the use of intestinally-cannulated sheep.

\section{References}

Argyle JL \& Baldwin RL (1989) Effects of amino acids and peptides on rumen microbial growth yields. Journal of Dairy Science 72, 2017-2027.

Barrie S \& Workman CT (1984) An automated analytical system for nutritional investigations using N-15 tracers. Spectroscopy International Journal 3, 439-447.

Binnerts WT, van't Klooster AT \& Frens AM (1968) Soluble chromium indicator measured by atomic absorption in digestion experiments. Veterinary Record 82, 470.

Broderick GA, Wallace RJ \& Ørskov ER (1991) Control of rate and extent of protein degradation. In Physiological Aspects of Digestion and Metabolism in Ruminants, pp. 541-592 [T Tsuda, Y Sasaki \& R Kawashima, editors]. London: Academic Press.

Carpenter KJ \& Booth VH (1973) Damage to lysine in food processing: its measurement and significance. Nutrition Abstracts and Reviews 43, 421-451.

Chataud J, Desreumaux S \& Cartwright T (1987) Procédé de préparation d'un mélange peptidique riche en di- et tri-peptides, utilisable notamment en nutrition artificielle et en diététique, mélange ainsi obtenu, et utilisation de ce mélange en nutrition artificielle et en diététique (Procedure for preparation of a peptide mixture rich in di- and tripeptides for use mainly in synthetic and therapeutic diets, the mixture itself, and its use in synthetic and therapeutic diets). Canadian Patent No. 86 17516.

Davidson J, Mathieson J \& Boyne AW (1970) The use of automation in determining nitrogen by the Kjeldahl method, with final calculation by computer. Analyst 95, 181-193.

Hecker JF (1974) Experimental Surgery in Small Ruminants, p. 126. London: Butterworths.

Kaufmann W \& Lupping W (1982) Protected proteins and protected amino acids for ruminants. In Protein Contribution of Feedstuffs for Ruminants, pp. 36-75 [EL Miller, IH Pike and AJH Van Es, editors]. London: Butterworths.

Leng RA \& Nolan JV (1984) Nitrogen metabolism in the rumen. Journal of Animal Science 67, 1072-1089.

Means GE \& Feeney RE (1971) Chemical modification of proteins. San Francisco, CA: Holden-Day, Inc.

Moore S \& Stein WH (1954) A modified ninhydrin reagent for the photometric determination of amino acids and related compounds. Journal of Biological Chemistry 211, 907-913.

Neuberger A \& Sanger F (1943) The availability of the acetyl 
derivatives of lysine for growth. Biochemical Journal 37, 515-518.

Neuhäuser M, Wandira JA, Göttmann U, Bässler KH \& Langer K (1985) Utilisation of N-acetyl-L-tyrosine and glycyl-L-tyrosine during long-term parenteral nutrition in the growing rat. American Journal of Clinical Nutrition 42, 585-596.

Poppi DP, MacRae JC, Brewer AC \& Coop RL (1986) Nitrogen transactions in the digestive tract of lambs exposed to the intestinal parasite, Trichostrongylus colubriformis. British Journal of Nutrition 55, 593-602.

Schwab CG (1995) Protected proteins and amino acids for ruminants. In Biotechnology in Animal Feeds and Animal Feeding, pp. 115-141 [RJ Wallace and A Chesson, editors]. Weinheim, Germany: VCH.

Van Goudoever JB, Sulkers EJ, Timmerman M, Huijmans JGM, Langer K, Carnielli VP \& Sauer PJJ (1994) Amino acid solutions for premature neonates during the first week of life - the role of $\mathrm{N}$-acetyl-L-cysteine and N-acetyl-L-tyrosine. Journal of Parenteral and Enteral Nutrition 18, 404-408.

Wallace RJ (1992a) Acetylation of peptides inhibits their degradation by rumen micro-organisms. British Journal of Nutrition 68, 365-372.
Wallace RJ (1992b) Gel filtration studies of peptide metabolism by rumen microorganisms. Journal of the Science of Food and Agriculture 58, 177-184.

Wallace RJ, Frumholtz PP \& Walker ND (1993) Breakdown of $\mathrm{N}$-terminally modified peptides and an isopeptide by rumen microorganisms. Applied and Environmental Microbiology 59, 3147-3149.

Wallace RJ \& McKain N (1989) Analysis of peptide metabolism by ruminal microorganisms. Applied and Environmental Microbiology 55, 2372-2376.

Wallace RJ, McKain N \& Newbold CJ (1990) Metabolism of small peptides in rumen fluid. Accumulation of intermediates during hydrolysis of alanine oligomers, and comparison of peptidolytic activities of bacteria and protozoa. Journal of the Science of Food and Agriculture 50, 191-199.

Witt MW, Newbold CJ \& Wallace RJ (1998) Influence of dietary acetylated peptides on fermentation and peptidase activities in the sheep rumen. Journal of Applied Microbiology (In the Press).

Wykes LJ, House JD, Ball RO \& Pencharz PB (1994) Aromatic amino acid metabolism of neonatal piglets. American Journal of Physiology 30, 672-679. 